\title{
What Factors Can Increase the Supply of Missing Middle Housing Types in Walkable Urban Core Neighborhoods? A Qualitative Study
}

By

Shrimatee Ojah Maharaj, University of South Florida

T here is a need for a variety of low-rise housing types in walkable urban core neighborhoods. These housing types once existed in the urban core, but are now missing. Daniel $\mathrm{Pa}$ rolek (CNU, 2018) proposed bringing back the Missing Middle Housing (MMH) types as one way to increase the supply. However, the risks of regulations, neighborhood opposition to increased densities, and apparent under-capitalization due to financing restrictions deter suppliers (developers) from helping to increase the supply. This qualitative study utilizing a grounded theory approach examines experts and industry leaders in the field supporting the claim that MMH types are "missing." A risk, risk reduction and capital flow mapping that influence supply emerged at the thematic portion of the research. This research suggests there is a willingness to solve the MMH types issue by mitigating the risks of all three factors of neighborhood opposition to density, lack of developer, and lender interests due to regulation and costs, which inhibit supply. Further research is necessary for mitigating the risks and infusing capital with the power brokers, the capital investors, and the suppliers.

Keywords: Missing Middle Housing types (MMH), Diverse Housing Types, Traditional Neighborhoods, Urban Core, Qualitative Data Analysis, Grounded Theory, NVivo, Barriers, Millennials, Boomers, Risk, Risk Reduction, Capital Flow, Supply in Housing

Copyright ( 2020, Shrimatee Ojah Maharaj. This article is published under a Creative Commons BY-NC license. Permission is granted to copy and distribute this article for non-commercial purposes, in both printed and electronic formats 


\section{Introduction}

Housing preferences are changing. Consumers are seeking smaller, well-designed units in walkable communities with easy access to shopping, entertainment, and public transportation (Myers \& Ryu, 2008; Woo, 2016). This is counter to the suburban-type dwelling offered by developers for the past decades (Doherty, 2017; Leyden, 2003; Myers \& Ryu, 2008). However, there is a lack of supply of the housing types that meet the demand. Efforts to reintroduce $\mathrm{MMH}$ in the urban core, where they once existed, have been met with opposition (Shaver, 2017).

Missing Middle Housing (MMH), a term coined by Daniel Parolek in 2010, described housing that existed in traditional neighborhoods in the urban core and some rural areas for decades in the early $20^{\text {th }}$ century (Leyden, 2003). They provided low rise, medium dense, affordable housing for diverse socioeconomic groups. Because of the compact design of the buildings, the mixed uses in the neighborhoods, and the grid-like layout of the streets, residents were able to live, work, play and walk in the neighborhoods for commerce and daily activities (Lucy \& Phillips, 2006). The compact housing provided the needed density for public transportation (Cervero, 1996; Congress of New Urbanism, 2018; Leyden, 2003; Parolek, 2016).

Due to changes in housing preferences for suburban type housing after World War II (WWII), new zoning and land use regulations were instituted to accommodate the suburban type development in the urban core. Consequently, the $\mathrm{MMH}$ types were regulated out of the urban core. Today, however, changing preferences and stage of life circumstances for both millennials and boomers point to an affinity for the benefits that MMH areas once offered (Myers \& Ryu, 2008; Woo, 2016)—among these: walkability, community, shopping, parks, restaurants, amenities and access to public transportation (Lucy \& Phillips, 2006).

At present, $\mathrm{MMH}$ types are in low supply in the urban core (Shaver, 2017) although remnants still exist in some areas (Lucy \& Phillips, 2006; Parolek, 2015; Vision 2020 Delegates, 2002). To address the imbalance between limited supply and high demand, Parolek provides an array of proposals for bringing back the MMH in walkable neighborhoods to help meet the growing demand of affordable housing (Opticos Design Inc., 2018). Implementing these would require retooling land use and zoning regulations to accommodate the densities and related parking (or lack thereof) for the MMH.
Urban planning practitioners and media assert there are barriers of neighborhood opposition to the higher densities, lack of lender interest for this type of development and, in consequence, lack of developer interest. The quest to meet the demands of this type of housing need is acute, especially in a strong economy and a healthy housing market (Shaver, 2017). The planners and developers may decide not to address the low supply of MMH in urban areas because of the barriers. Instead, they may go to alternate areas where there are fewer obstacles to the MMH types.

The purpose of the research described in this paper was to conduct an in-depth study of the perceived issues, applicability and potential solutions relating to expanding $\mathrm{MMH}$ in the Tampa Bay area. The Tampa/St. Petersburg MSA is a region with an Area Median Income of $\$ 53,700$ for a single household, $\$ 61,350$ for a household of two, and $\$ 76,700$ for a household of four (Florida Housing Finance Corporation, 2018). The housing type addressed in this research, is "market rate" affordable housing or non-subsidized workforce housing.

Developer financing is revealed as one of the issues affecting the supply of market-rate affordable housing (Ojah Maharaj, 2020). Among others, two federal programs support low to moderate-income housing development: The Low-Income Housing Tax Credits (LIHTC) for large developers and the Community Reinvestment Act (CRA) for lending institutions. The LIHTC was created in 1986 for the Department of Housing and Urban development to incentivize developers to build affordable housing in urban core areas targeted for lower-income households. LIHTC provides approximately $\$ 8$ billion annually in tax credit authority to local and state entities to issue tax credits for various aspects of development (HUD User, 2019).

Furthermore, the Community Reinvestment Act (CRA) of 1977 was designed to spur lending institutions to provide loans (commercial, residential, farm) to their resident communities to help meet the credit needs for low to moderate-income neighborhoods (https://www.ffiec.gov/cra/history.htm). The regulation required recording and reporting this information. This information is critical when the institutions apply for mergers and acquisitions and other deposit facilities (https://www.ffiec.gov/ cra/history.htm). However, the growing demand for affordable market-rate housing, which is accessible to amenities such as shopping, entertainment and other services in urban areas (missing middle hous- 


\section{Methodology}

This research was conducted over a nine-month period. Research subjects were leading practitioners, upper and middle management professionals, developers, and industry leaders in Tampa Bay, Data collection was guided by Corbin and Strauss' grounded theory qualitative methodology (Corbin \& Strauss, 2014).

The methodology comprises of data collected from interviews, open coding, axial coding, and selective coding (Creswell, 2013). Open coding could consist of a word, line by line or a paragraph; axial coding (a cluster of open codes), memo writing, which is part of the inductive process of theory development (Creswell, 2013). When theoretical saturation is achieved, data collection stops. The process continues with selective coding and theoretical modeling. Unique to Corbin and Strauss's qualitative study methodology is a constant comparison process (Creswell, 2013). This process requires the researcher to constantly compare the coded item and the category with previously coded items for similarities or differences, this eliminates the need for a hypothesis and avoids biases (Creswell, 2013; LaRossa, 2005).

Data was derived from interviews with thirty-nine leaders and practitioners. Data collection for this research spanned a period of 3.25 months. Interviews had an average duration of 59 minutes each.
Data collection and preparation (coding and memos) took a total of 187 hours, with an average of 4.79 hours per interview. NVivo 12 Plus software was used to prepare the data (code the interviews).

The areas of expertise covered urban planning, historic preservation, transportation planning, permitting and reviews, housing and economic development, development, policy, lending, and sales. The categories of interview subjects were as follows:

- Practitioners: Local and County Government Administrators, CEOs, Managers, and Mid-level staff (including two millennials);

- Policy/Special Interest: Private and Public Sector Real Estate professionals, Land Use and Zoning Attorneys, Area-wide revitalization/historic preservation leaders, Chamber of Commerce President and Local Government Council Member;

- Realtors: Owner/Broker and President of the County Realtors Association, Real Estate Associate;

- Lenders: Community, and mid-size bank leaders, and an organization that works with a consortium of banks; and

- Developers: Large and small, local and state-wide developer, architect/design-build.

The breakdown of interviewees is presented in Figure 2 .

\section{Type of Contributors}

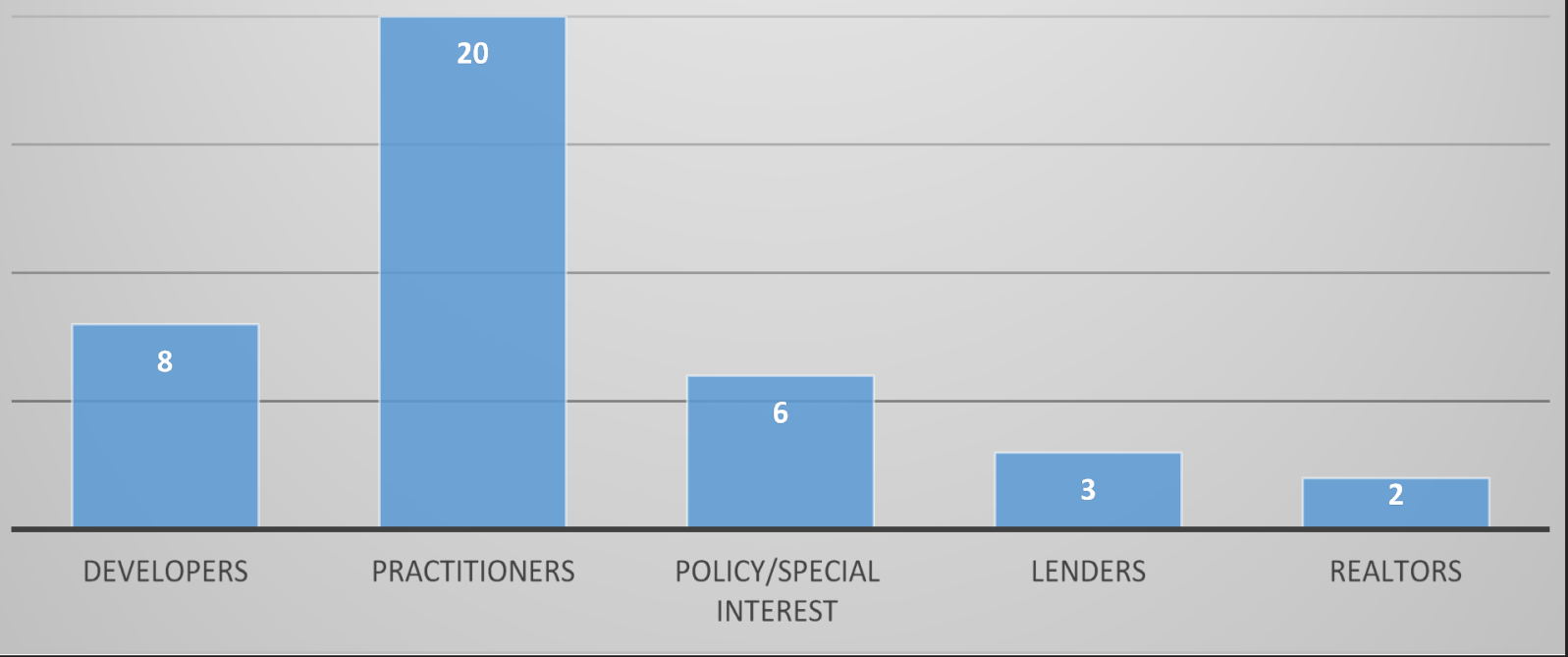

Figure 2. Types of Respondents by Category 
ing), is lacking in supply and is costly (Ojah Maharaj, 2020; Shaver, 2017). Though there is a demand for the housing type, there are barriers such as land use and other developmental regulations. When contrasted with the two previous programs, there is a lack of developers' and lenders interest (Ojah Maharaj, 2020). Details of these reasons are revealed further in this research.

The paper begins with a brief overview of research findings relating to $\mathrm{MMH}$; a more detailed survey can be found in Ojah Maharaj (2020). An overview of the research methodology is then provided, followed by a presentation of the research findings. The findings are then discussed, leading to the introduction of a risk flow, risk reduction, capital flow model intended to help us better understand the forces that lead to the more widespread construction of MMH. Finally, the paper concludes with some concrete suggestions for different stakeholders and potential directions for future research.

\section{Review of Research}

High performing economic areas attract the best talent, which has an impact on the supply of housing (Glaeser \& Gyourko, 2018). Geographically landlocked areas, such as Pinellas County and parts of Tampa, Florida, impact available land to build and thus affect the supply of housing. This is amplified when the area has other attractors such as weather and amenities (Glaeser \& Gyourko, 2018).

Quality of life issues (housing, amenities, schools, healthcare, and others), particularly the type, cost, and availability of housing, are important factors companies consider when starting or relocating a business to an area. These factors directly impact a company's ability to attract the best talent (Area Development, 2009). Thus, city and business leaders are seeking ways to improve their housing supply (Area Development, 2009).

The MMH types in urban core areas are suggested as one way to help improve the supply (Congress of New Urbanism, 2018). A prior article, Ojah Maharaj (2020), presented a systematic review of the forces affecting MMH. In brief, there are many factors that affect the supply of a variety of low to mid-rise, affordable housing in walkable urban areas. Some of the major challenges include land use and zoning restrictions (Koebel, Lang, \& Danielsen, 2004; Kolson, 2016), neighborhood opposition (Doherty, 2017; Koebel et al., 2004), lack of developer interest in building these units, lack of financing, limited land available, and high land and construction costs (Burks, 2017; Koebel et al., 2004; Kolson, 2016; Shaver, 2017). Intervention strategies to overcome the barriers include: regulatory changes to increase density and provide incentives to developers and home-owners; educating the neighborhoods to allay their fears of increased density, working with developers to address their issues and working with lenders to create financial tools for developers.

Figure 1 provides a graphic depiction of the challenges and potential solutions. In interpreting the figure, the key objective should be increasing the supply

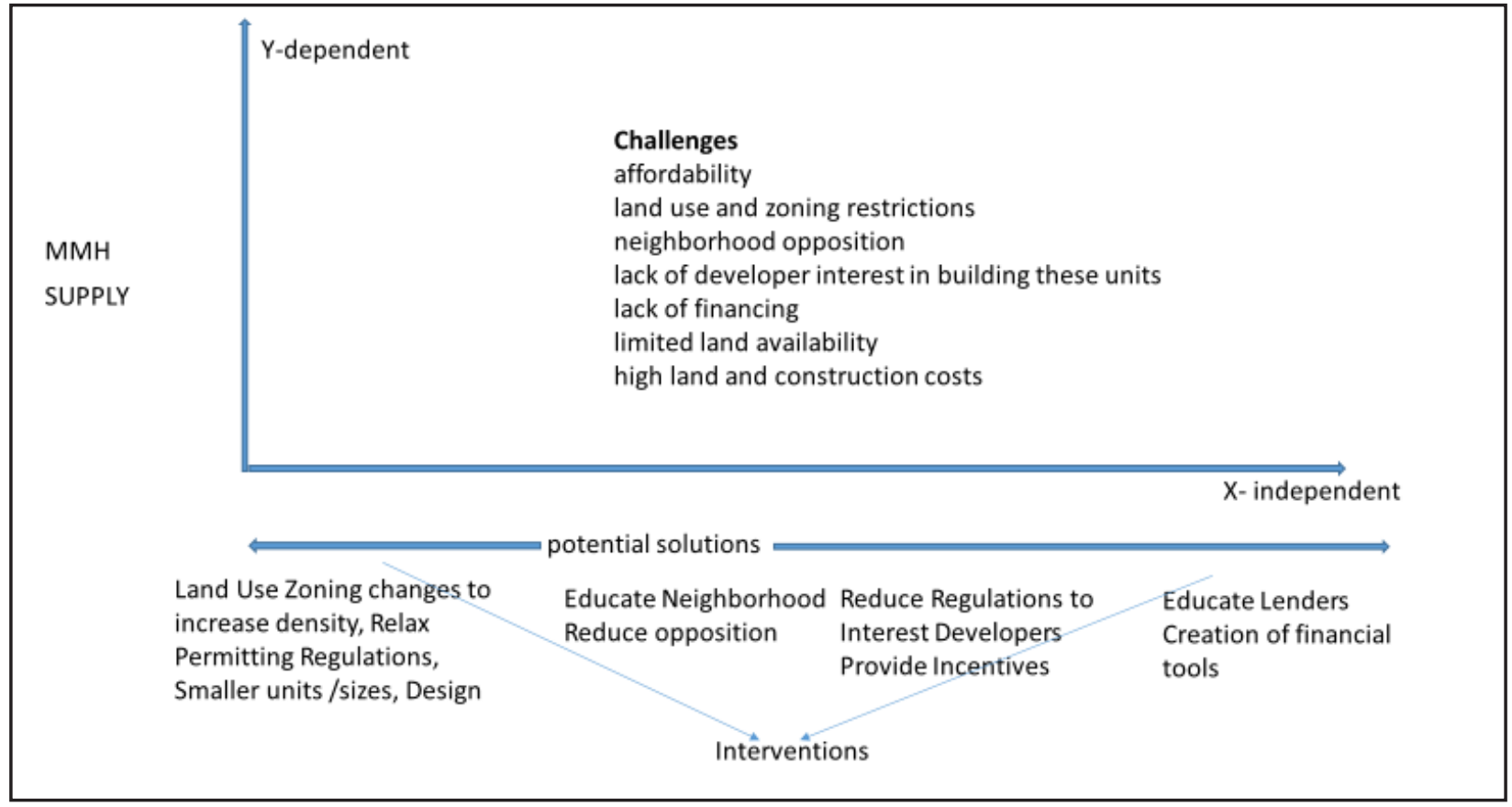

Figure 1. A Graphic Representation of a Summary of the Major Findings / Factors Which Affect the Supply of MMH Types (Ojah Maharaj, 2020) 
(DV, dependent variable, Y-axis) of MMH types in urban core neighborhoods. Based on an earlier literature review (Ojah Maharaj, 2020), the major factors that negatively affect the supply (located under "Challenges" in Figure 1), include affordability, land use, and zoning restrictions, neighborhood opposition, a lack of developer interest in building the units, a lack of lender financing, limited land availability, and high land and construction costs. The literature also proposes potential solutions/interventions (IV, Independent Variable, X-axis) such as (1) land use and zoning regulation changes to increase density, (2) relaxing permitting regulations, (3) building smaller units to compensate for the high cost of land and construction, (4) educating the neighborhoods to reduce opposition to increased density, (5) reducing regulations to interest developers, (6) providing incentives, and (7) other interventions, such as educating lenders and creating financial tools for developers.

\section{Findings}

During the interview process, nearly all respondents referred to two broad categories: supply problems and supply solutions. Specifically, of 39 individuals interviewed, 37 (95\%) identified items relating to supply problems and 38 (97\%) to supply solutions. The broad categories and items classified during the interview process, ordered by subcategory, are summarized in Figure 3, with supply problems on the left and supply solutions on the right.

\section{Supply Problems, Supply Solutions}

A variety of interrelated topics were identified through axial coding under the heading of "supply problems" and "supply solutions." The number of responses for each of these topics is presented in Figures 3, 4 and 5. From these topics, a number of key categories emerged.

\section{Supply Problems Transportation, land use and transit}

The majority of respondents $(34,87 \%, 65$ times mentioned) identified problems in this category. They also recognized these factors were a challenge to solve. Because increased density supports transit, there was a dilemma with respondents as to which should come first. Service needs ridership and frequency. Ridership needs density. However, as described next, there are major issues to resolve with density.

\begin{tabular}{|c|c|c|c|c|c|c|c|c|c|}
\hline \multirow{2}{*}{$\begin{array}{l}\text { Axial Code/Category/Themes } \\
\text { Supply Problem }\end{array}$} & \multirow{2}{*}{$\frac{\frac{\tilde{U}}{\tilde{L}}}{37}$} & & \multirow[t]{2}{*}{ 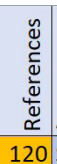 } & \multicolumn{3}{|c|}{ Axial Code /Category /Themes } & \multirow{2}{*}{$\frac{\frac{\mathscr{\omega}}{\tilde{E}}}{38}$} & $\%$ & \multirow{2}{*}{ 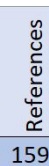 } \\
\hline & & $95 \%$ & & Supply Solu & tions & & & $97 \%$ & \\
\hline Transportation, Land Use \& Transit & 34 & $87 \%$ & 65 & Overcome & Barriers & & 34 & $87 \%$ & 38 \\
\hline Affordability & 22 & $56 \%$ & 57 & Density & & & 26 & $67 \%$ & 57 \\
\hline Complexity due to factors below & 11 & $28 \%$ & 18 & \multicolumn{3}{|c|}{ Go To Major Streets and Corridors \& Hard to Develop Areas } & 13 & $33 \%$ & 18 \\
\hline Demand Problem/High Demand & 27 & $69 \%$ & 33 & \multicolumn{3}{|c|}{ Density for Mass Transit } & 19 & $49 \%$ & 49 \\
\hline Desirable Neighborhoods - Walkable areas \& Amenities & 10 & $26 \%$ & 15 & \multicolumn{3}{|c|}{ MMH Current Situation Opportunities } & 13 & $33 \%$ & 65 \\
\hline Neighborhood Power \& Influence with Politicians & 7 & $18 \%$ & 12 & \multicolumn{3}{|c|}{ Historically Owner Occupied } & 7 & $18 \%$ & 19 \\
\hline Density: Neighborhood Opposition \& Save The Burg & 5 & $13 \%$ & 6 & \multicolumn{3}{|c|}{ Developers } & 12 & $31 \%$ & 32 \\
\hline Neighborhood Fear of Change, Renters, Prior Experience & 13 & $33 \%$ & 16 & \multicolumn{3}{|c|}{ Regulations Related \& Fee Reduction Related } & 8 & $21 \%$ & 14 \\
\hline Emotions, Feelings, Safety, Stability & 14 & $36 \%$ & 20 & \multicolumn{3}{|c|}{ Defray Construction Costs } & 13 & $33 \%$ & 14 \\
\hline Perceptions & 13 & $33 \%$ & 15 & \multicolumn{3}{|c|}{ Incentives } & 12 & $31 \%$ & 19 \\
\hline Developer Challenges & 14 & $36 \%$ & 21 & \multirow{2}{*}{\multicolumn{3}{|c|}{ Make City Vacant Land Available to Developers }} & 4 & $10 \%$ & 15 \\
\hline Developer Perceptions of MMH - Difficult to do & 5 & $13 \%$ & 7 & & & & & & \\
\hline Barriers & 17 & $44 \%$ & 54 & Strategies & & & 11 & $28 \%$ & 38 \\
\hline Regulations & 14 & $36 \%$ & 19 & \multicolumn{3}{|c|}{ Steps Taken to Increase Supply } & 3 & $8 \%$ & 3 \\
\hline The Process is Too Long & 6 & $15 \%$ & 7 & \multicolumn{3}{|c|}{ Repurpose and Redevelop - Historic Preservation } & 3 & $8 \%$ & 4 \\
\hline Property Values \& Construction Costs are High & 7 & $18 \%$ & 10 & \multicolumn{3}{|c|}{ Efficiency in Permitting \& Construction } & 2 & $5 \%$ & 14 \\
\hline Barriers to MMH \& Market Forces & 10 & $26 \%$ & 18 & \multicolumn{3}{|c|}{ Educate the Neighborhoods } & 6 & $15 \%$ & 6 \\
\hline Lenders & 10 & $26 \%$ & 20 & \multicolumn{3}{|c|}{ Educate Developers \& Share Information } & 5 & $13 \%$ & 8 \\
\hline Barriers & 9 & $23 \%$ & 14 & Lenders & & & 7 & $18 \%$ & 10 \\
\hline Banks are Risk Averse & & & & \multicolumn{3}{|c|}{ Dodd Frank Not a Problem } & 2 & $5 \%$ & 2 \\
\hline Dodd Frank & 3 & $8 \%$ & 3 & \multirow{2}{*}{\multicolumn{3}{|c|}{ Practitioners Need to Work with Lenders \& This should be }} & 9 & $24 \%$ & 20 \\
\hline Lenders Not Financing & & & & & & & & & \\
\hline Challenge to lend Smaller Entities Financials Not in Order & & & & \multicolumn{3}{|c|}{ Working on a program to help developers and borrowers } & & & \\
\hline See Notes in certain cells & & & & \multicolumn{3}{|c|}{ Help Small Developers with Financials } & & & \\
\hline \multicolumn{10}{|l|}{ White $=A$ combination of various groups } \\
\hline Lenders & & & & & & & & & \\
\hline Developers & & & & & & & & & \\
\hline Neighborhoods & & & & & & & & & \\
\hline A suggestion to forget the urban core and go outside & & & & & & & & & \\
\hline High demar & & & & e nistructe & labor & & & & \\
\hline
\end{tabular}

Figure 3: Supply Problems, Supply Solutions, Axial Codes. See Appendix 1 for codes by Stakeholder 


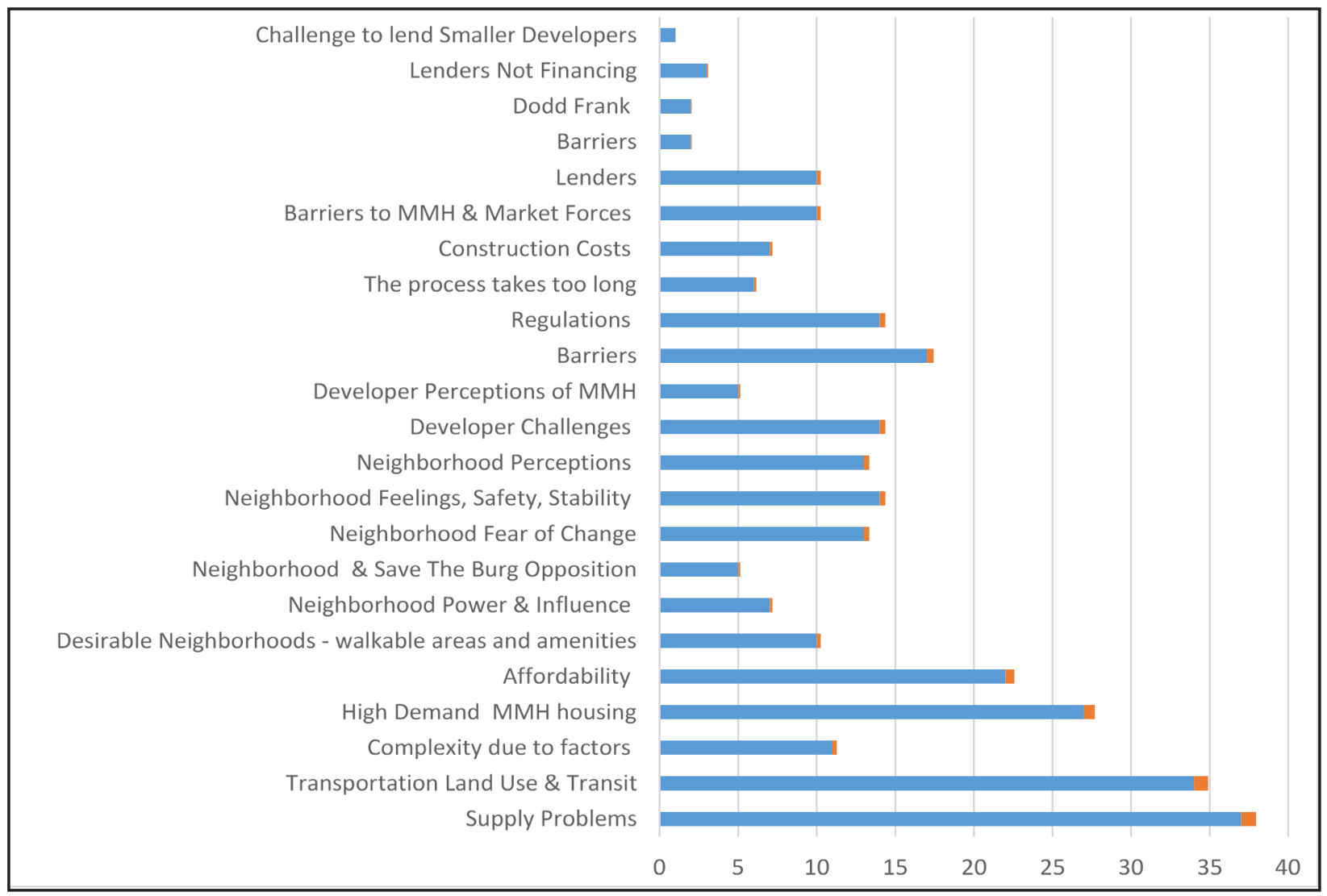

Figure 4: Supply Problems by the Number of Respondents as Extracted from the Interviews

\section{Density}

Due to the limit of land availability in the older urban core neighborhoods, increased density appears to be the way to increase the MMH types in these neighborhoods. Density reveals itself as a problem for the neighborhoods in the form of neighborhood opposition due to fear about the safety and stability of the neighborhoods $(14$, or $36 \%, 20)$; and regarding their perceptions of the type of residents associated with poverty and poor construction and design $(13$, or $33 \%, 16)$. Complexity of the supply problem is increased as respondents were cognizant of the power and influence neighborhoods have with the politicians $(7$, or $18 \%, 12)$ in preventing increases in density in desirable neighborhoods. Respondents identified the neighborhoods and a historic preservation group that opposed the potential of increased density $(5$, or $13 \%, 6)$. Developers' perceptions (5, or $13 \%, 7)$, challenges $(14$, or $36 \%, 21)$ and issues also rose to add to the complexity.

\section{Affordability}

Of the 39 individuals interviewed in this research, 37 (or 95\%) indicated there is a supply problem with $\mathrm{MMH}$ types / affordable housing for the median income household. This was referenced 120 times during the interviews, which indicates a very significant concern.
The problem of affordability was exacerbated by $\mathrm{MMH}$ demand outstripping supply. Sixty-nine percent $(69 \%)$ of the respondents recognized there was a high demand for MMH types, mentioned this as a problem 33 times during the 27 interviews.

\section{Developer Barriers (see Appendix 1)}

Developer's barriers, challenges, and perceptions were cited as issues to the supply problem of the MMH types (See Appendix 1). Barriers were mentioned 54 times during 17 interviews. They included Regulations (14, or 36\%, 19 times). Government regulations, such as requirements for off-street parking and variances to the land use and zoning regulations to build MMH types in the urban core, make the process lengthy $(6$, or $15 \%, 7)$.

Although eight developers participated in this research, high-ranking issues such as developer's challenges $(14$, or $36 \%, 21)$, barriers $(17$, or $44 \%, 54)$, barriers to the MMH types, and market forces (10, or $26 \%, 18$ ) were discussed by more than eight respondents. The cost-effectiveness of building MMH types within the constraints of regulations and neighborhood opposition was of concern to the respondents. Market forces, such as the high cost of land, labor, and construction costs were cited as impediments to the MMH types.

This indicates that respondents outside of the de- 


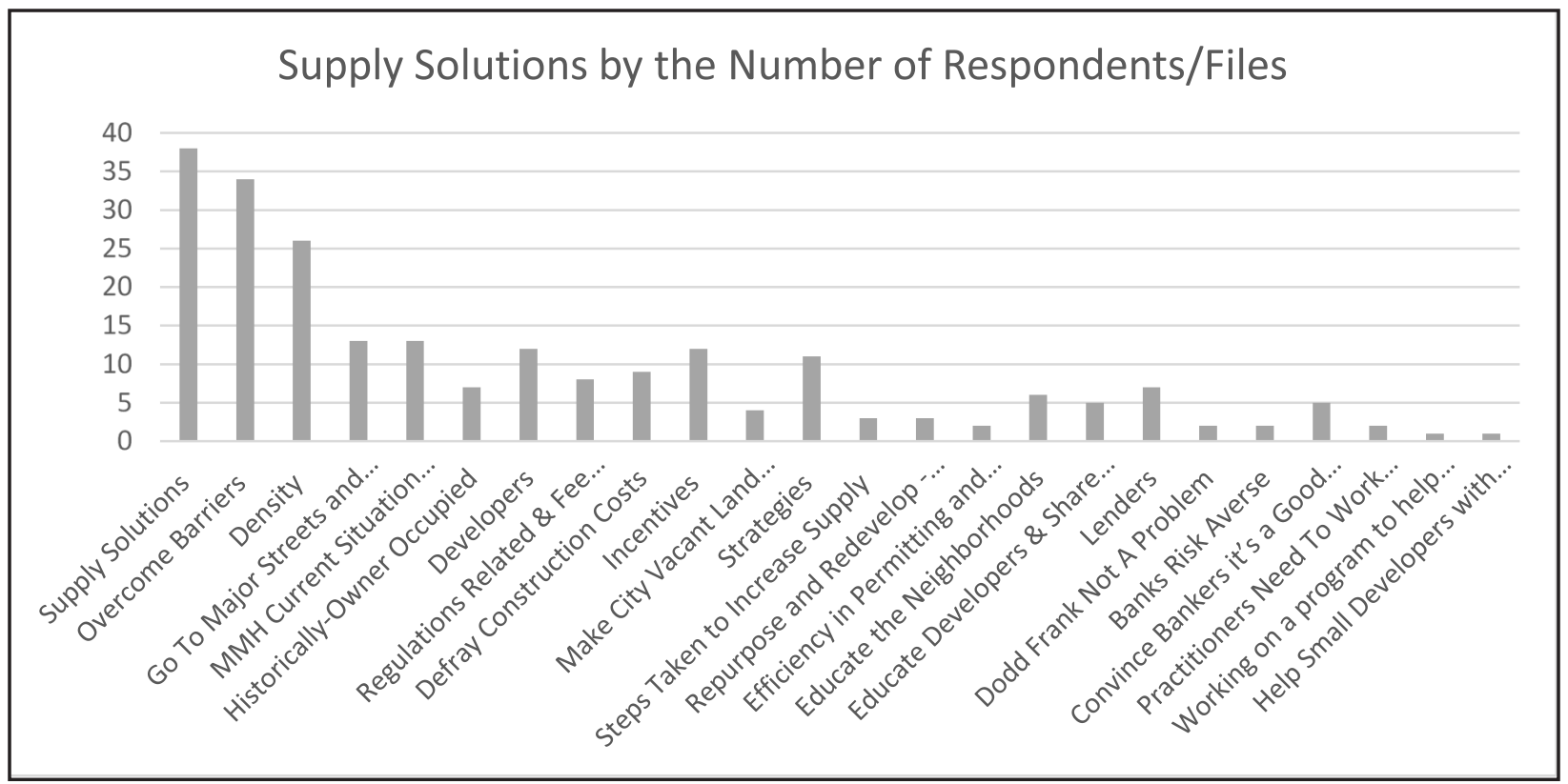

Figure 5: Supply Solutions, by Number of Respondents, Extracted from the Interviews

veloper's group were talking about developers and their role in the supply problem and supply solutions for increasing MMH types in urban core neighborhoods. This is also an indication of the significant role that developers play or can play in increasing the supply of MMH types. Developers' challenges $(14$, or $36 \%, 21)$ emphasized neighborhood opposition, regulations, lenders resistance to provide loans and the cost of construction. Their perceptions were that the MMH types are difficult to do $(5$, or $13 \%, 7)$. Challenges include those discussed above as well as the difficulty and costs involved in staging a job in the urban core.

\section{Lender Barriers}

Although three lenders participated in this research, ten interviews addressed the role of lenders in the supply problem $(10$, or $26 \%, 20)$. The findings indicate that lenders are a hindrance to the supply of the MMH types in the walkable urban core neighborhoods because they are not financing such loans. Dodd-Frank (Wall Street Reform \& Consumer Protection Act, 2009) was specifically referenced as a problem for lenders and as a possible reason why lenders were not financing the MMH types (3,8\% 3 times).

\section{Supply Solutions (Risk Reduction) (Ap- pendix 1)}

Thirty-eight (38) out of 39 respondents talked about supply solutions for the MMH types. This was mentioned 159 times during those interviews. Thirty-four (34) of the respondents (87\%) echoed the need to overcome the barriers to increase the supply of $\mathrm{MMH}$ types in the urban core neighborhoods.
Thus, it was almost an equal amount recognizing a supply problem of the MMH types in urban core neighborhoods and a need to find solutions to increase the supply. Figure 5 presents terms extracted from interviews relating to solutions, showing both the number of respondents and the number of times each term was mentioned.

In each of the areas where supply problems were mentioned, a variety of potential solutions were also proposed. These are now summarized.

\section{Transportation, Land Use and Transit}

As previously noted, transportation, land use, and transit ranked very high, $(34,87 \%, 65)$ on the supply problem side. While transportation and transit do not have a direct effect on the supply, it is perceived to be a result of the supply. Almost fifty percent $(50 \%)$ of the respondents discussed density as a need to support transit and transportation; however, respondents were not sure which comes first: the density to support the MMH types and transit/ transportation or the transportation to support the MMH types.

Respondents responded to these issues in three ways: (1) go to the major streets and activity centers to provide increased densities, which will support transit and avoid neighborhood opposition; (2) work locally on pedestrian and bike-friendly strategies such as widening sidewalks, narrowing streets, creating bike lanes to provide a sense of security in the streets for walkability and bike-ability; and (3) work on transit-oriented development techniques such as off-street parking requirements, and incentives for developing on the major corridors to encourage development. 


\section{Density}

Density was the leading way suggested to increase supply. Twenty-six (26) of the respondents (67\%) talked about increasing density 57 times during the interviews as a solution to increase the $\mathrm{MMH}$ types. Although there is opposition to density from the neighborhoods, solutions to increase the MMH types included:

- Educating the neighborhoods through the "appropriate messaging" about the type of density, the benefits, the residents who live in these units, measures taken to mitigate their concerns of compatibility with the neighborhood, and noise and disruption (staging) during construction $(6$, or $15 \%, 6)$ (Interview \#36).

- Working with developers to address their concerns of restrictive regulations on land use and zoning, off-street parking requirements, high costs for permitting fees and providing incentives $(12$, or $31 \%, 19)$, such as making vacant city land available to developers to construct MMH types (12, or $31 \%, 32$ ) (Interviews \#4, 5, 7).

- Educating and informing developers (5, or $13 \%, 8)$ about incentives and areas that have the land use and zoning in place for "MMH types i.e. MMH types-ready," and informing developers of the processes in place to address their concerns of lengthy delays for site plan reviews and permitting approvals, i.e., "Time-to-Market" issues/ concerns (Interview \#6).

- Considering new strategies shared by practitioners / respondents $(11$, or $28 \%, 38)$ such as: updating land use / zoning regulations to accommodate higher densities for MMH types; loosening off-street parking requirements; allowing for accessory units in single-family neighborhoods; and implementing "Complete Streets" techniques to make the area more pedestrian-bike friendly (Interviews \#4, 27).

- Respondents also proposed to repurpose and redevelop multi-unit properties to increase the supply of MMH types (3, or $8 \%, 4)$ (Interview \#33).

- Working with lenders (7, or 18\%, 10). Although three lenders participated in this research, a total of seven respondents provided suggestions on working with lenders to increase the supply of MMH types in the urban core, while it appears, lenders stated their constraints and capabilities (Interview \#37)

\section{Affordability}

Affordability ranked the 4th highest $(22,56 \%, 57)$, on the supply problem side of this issue. Thirty-three percent $(33 \%)$ of the respondents recognized there are opportunities in developing the $\mathrm{MMH}$ types. This was mentioned 65 times during the 13 interviews. Respondents saw the affordability issue as being intrinsic to the MMH types; "the area is desirable, and people want to be here."

While respondents continued to employ strategies such as land use and zoning changes incrementally to encourage MMH types, they continued to express concern on affordability due to high land and construction costs, high demand (Market Forces) and described it as a challenge. Respondents suggested increased density, relaxed regulations, design techniques and incentives such as parking fee waivers, and available city land for constructing MMH types as ways of reducing costs.

\section{Developer Barriers}

The cost-effectiveness of building MMH types within the constraints of regulations and neighborhood opposition was of concern to the respondents. Market forces, such as the high cost of land and construction costs were cited as impediments to the MMH types. Respondents viewed this as a challenge. To address the challenge, respondents suggested, permitting incentives such as waiving parking and permitting fee, increasing density, density bonuses, providing vacant city land for development and making the process more efficient (Interviews \#1, 11, 15).

\section{Lender Barriers}

Respondents indicated "Banks are risk averse." Lenders indicated their goal is "to protect the depositor" $(2$, or $5 \%, 4)$ and Dodd-Frank is not an issue $(2,5 \%, 2)$. It requires more paperwork and oversight on bank practices such as loans. Lenders do not make loans for properties that are four units or less. Developers must convince bankers it's a good investment $(5$, or $13 \%, 15)$. Historically, such units had a resident manager. Practitioners need to work with lenders and developers to understand and find a way to bridge the gap in lending $(9,24 \%, 20)$.

There were three lending respondents in this research. One of the lenders commented, "small developers do not have their finances in order." This could be an indication that there were attempts to finance small developers' projects, and there may be a remedy for this challenge (Interview \#37). 


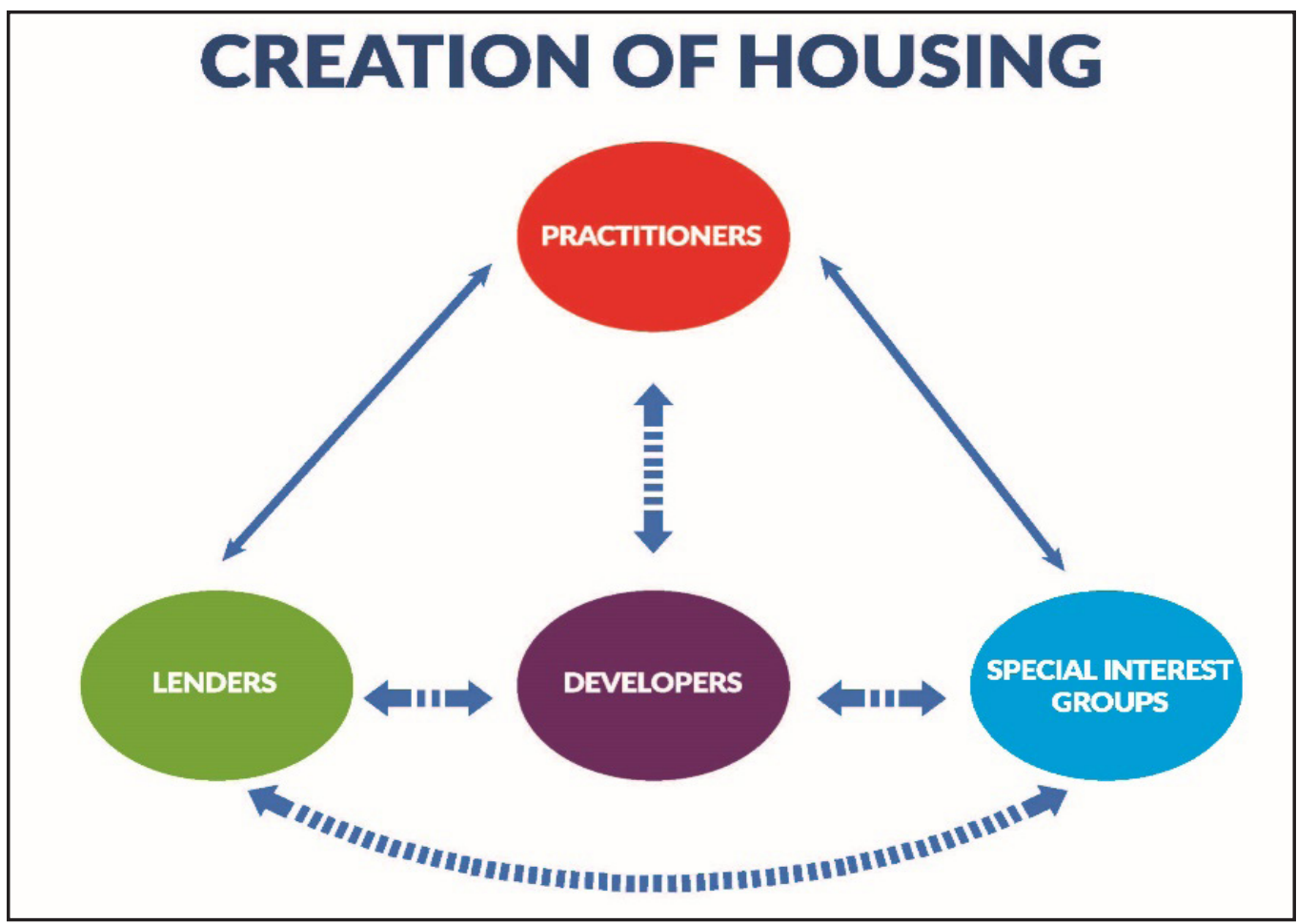

Figure 6: Creation of Housing

One practitioner respondent expressed the need for "nurturing a group of small local developers" as a solution to increasing the supply of the MMH types in the urban core. As she stated, "They live here, I know them, I hear them, they are passionate about what they do; we work with them, they understand our vision. They know the neighborhoods and provide a great product." "It is a good way to increase the supply incrementally" (Interview \#31).

Another respondent expressed mistrust by the community and the need to look at housing in a holistic manner. This respondent repeatedly expressed the

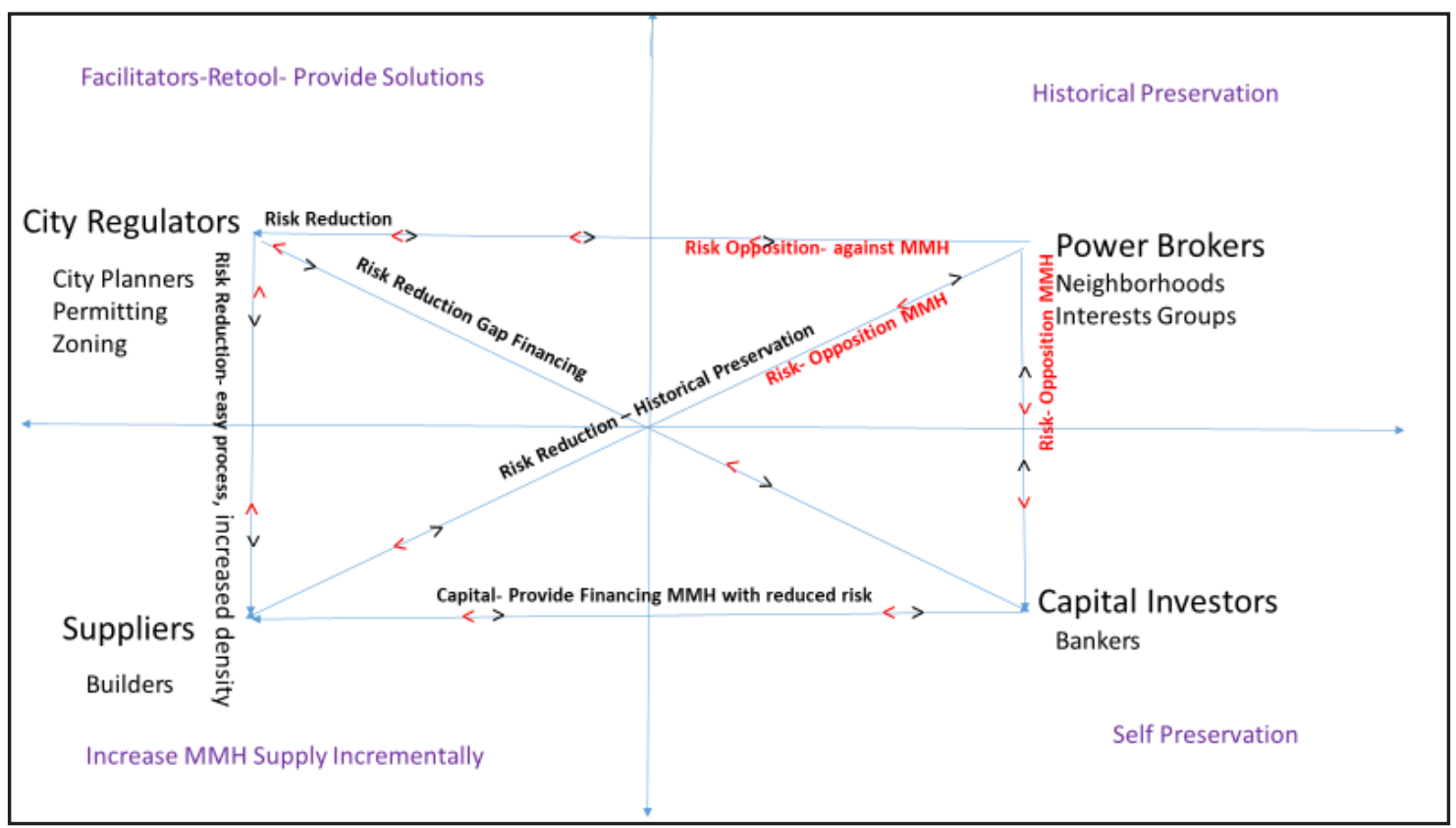

Figure 7. Comparison Grid. Theme: Risk Flow represented by (red), Risk Reduction (black), Capital Flow represented by (black) 
Table 1. List of Supply Problem and Supply Solutions for each stakeholder category taken from Figures 4 and 5. Risk Flow is assigned by (-), Risk Reduction and Capital Flow is assigned by $(+, \$)$

\begin{tabular}{|c|c|c|c|c|}
\hline Category & $\begin{array}{l}\text { Suppliers/ } \\
\text { Developers/ } \\
\text { Builders }\end{array}$ & $\begin{array}{c}\text { Power Brokers/ } \\
\text { Influencers } \\
\text { Neighborhoods, } \\
\text { Special Interest } \\
\text { Groups }\end{array}$ & $\begin{array}{c}\text { City Regulators (Plan- } \\
\text { ning, Development } \\
\text { Review, Permitting) }\end{array}$ & $\begin{array}{c}\text { Capital Investors } \\
\text { (Lenders) }\end{array}$ \\
\hline Risk Flow & $\begin{array}{l}\text { Land Use and Zoning } \\
\text { Restrictions } \\
\text { Long Process } \\
\text { Opposition } \\
\text { No MMH }\end{array}$ & $\begin{array}{l}\text { Density } \\
\text { Poor Design } \\
\text { Property Devalue } \\
\text { Status Quo } \\
\text { Neighborhood Control } \\
\text { Opposition }\end{array}$ & $\begin{array}{l}\text { Restriction on density, } \\
\text { land use \& zoning } \\
\text { Power Brokers Opposi- } \\
\text { tion to density }\end{array}$ & $\begin{array}{l}\text { MMH } 4 \text { units or } \\
\text { less } \\
\text { Not their market }\end{array}$ \\
\hline $\begin{array}{l}\text { Risk Re- } \\
\text { d u c t i o n } \\
\text { C a p i t a l } \\
\text { Flow }\end{array}$ & $\begin{array}{l}\text { +Time \& Time to Mar- } \\
\text { ket } \\
\text { - } \quad \text { +No Opposition } \\
\text { - } \quad \text { +Incentives } \\
\text { - } \quad \text { +Easy \& Simple } \\
\text { - } \\
\text { +Revise Land Use } \\
\text { and Zoning to } \\
\text { higher densities }\end{array}$ & $\begin{array}{ll}- & + \text { Assurances } \\
- & + \text { Historic Integrity } \\
- & + \text { Repurpose \& } \\
& \text { Expand Existing }\end{array}$ & $\begin{array}{l}\text { - } \\
\text { - Incentives } \\
\text { Vacant land to Sup- } \\
\text { pliers } \\
\text { +Willing to facilitate, } \\
\text { retool, Support } \\
\text { +Educate Power } \\
\text { Brokers } \\
\text { +Educate Capital } \\
\text { Investors } \\
\text { +Gap Financing to } \\
\text { Capital Investors } \\
\text { +Remove Imped- } \\
\text { iments to MMH } \\
\text { types Densities }\end{array}$ & - Gap Financing \\
\hline
\end{tabular}

concern for the issue to be addressed in a comprehensive manner. That is, it must take the economic, social and environmental factors of an area into account. The respondent also expressed the need to work with local developers who understand the community and are here "for the long haul" This statement was made about major commercial projects in partnership with the city and on the supply of the MMH types (Interview \#39).

\section{Discussion}

Overall, the preliminary overview revealed an interrelatedness among the stakeholders as indicated in Figure 6. The graphic anchors the roles and interactions of the stakeholders for further analysis as seen in Figure 7 and Table 1.

As the findings from the interviews became clear, a picture began to emerge that began with a synthesis of the participant types (stakeholders) into four broad classes based upon the broad roles they play in the process. These specific stakeholder roles are as follows:

- City Regulators: formerly Practitioners

- Suppliers: formerly Developers

- Capital Investors: formerly Financiers, Lenders
- Power Brokers: formerly Neighborhood and Special Interest Groups

Using these roles, it was possible to present the relationships in the form of a synthesized risk flow, risk reduction, and capital flow model.

\section{Risk and Capital}

The evaluation of risk or uncertainty starts with evaluating risk and its impact on the success of your goal (Hertz, 1979). The principle of risk is measured by the degree of uncertainty of risks combined (Hertz, 1979). For the purposes of this research, risk is defined as barriers that decrease the chance of success. The more barriers, the higher risk. Specifically, the barriers to increase supply of MMH (neighborhood opposition, regulations, high costs of land, construction and financing, reduced developer and banker interests). The evaluation of a capital investment (time, money, assets, resources) starts with the principle that the productivity is measured by the rate of return the stakeholders expect to receive over some future period (Hertz, 1979; Rao, 2013).

Specifically, for the purposes of this research, capital is defined as the stakeholders' money. Risk reduction is time, effort resources, and assets they invest to receive the expected capital return on their invest- 
ment. From the city's/local government's perspective, their risk reduction will be meeting the needs of neighborhoods, developers/builders, bankers, and buyers with the overall goal of increasing the supply of $\mathrm{MMH}$ at reduced risk. From the perspective of the neighborhoods, their risk reduction investment of time and effort is to meet the design criteria and compatibility of the neighborhood, address parking and transportation needs, and then property values will increase. From the perspective of developer/ builder, they will get satisfaction in building quality $\mathrm{MMH}$ for their customers, recognition from the city, and bankers, and receive the same amount of return with less risk. From the perspective of the bankers, they will meet the needs of the developer/builder and buyers and get the satisfaction of a successful loan program specifically for $\mathrm{MMH}$, with less risk and same return. The goal of risk mitigating planning is to reduce the uncertainty/risk or barriers involved from the stakeholder's perspective through lessening or eliminating the barriers with solutions. Reducing the risk/uncertainty or barriers with solutions makes the capital investment more attractive to the stakeholders who will receive the same amount of expected return with less risk.

Figure 7 was derived from relationships identified from the interviews during the open coding process. Specifically, the supply problems (risks) (Figure 4) and supply solutions (risk reduction, capital) (Figure 3) derived from the interviews and data analysis of thirty-nine respondents in this research. The data transformation moves from Axial Codes to thematic. Upon a comparison of the four grids, as represented in Figure 7, there are bi-directional interactions with the four groups of stakeholders. It reveals the stakeholders' influence, needs, and risks. Risks are represented by red labels, and capital (money) is represented by black. Risk reduction is representative of services and incentives is represented by black labels. There is a theme of risk, risk reduction, and capital. Risk reduction can be in the form of services/support and capital money. Risks can be in the form of neighborhood opposition, delays in projects. Each quadrant holds a stakeholder and the corresponding risks, risk reduction and or capital.

There is a concentration of risk flow, risk reduction, and capital flow or (lack of) among the power brokers (neighborhood), the Suppliers (developers) and the city regulators, which is impeding the flow of capital from the capital investor (Figure 7). The bi-directional flow of risks, risk reduction, and capital is significant as it indicates the process can be managed depending on the desired outcome. In this case, it is to improve the supply of MM types.

Table 1 summarizes the risk flow, risk reduction and capital flow for the suppliers, the power broker/influencers, the city regulators and the capital investors in the supply of the MMH types from Figure 7.

\section{Key Risk, Risk Reduction and Capital Relationships}

Two particularly important relationships were identified in the analysis of the risk, risk reduction, and capital flows:

Increasing Risk Flow inhibits (attenuates) capital flow and consequently, suppresses the supply of MMH types, "Time and Time to Market."

As one city regulator stated during an interview "Time and Time to Market" is very important to the supplier (Interview \#6). Thus, any action, policy, or event which hinders, slows the process or delays the product to market is a risk to the Supplier and ultimately to the supply of the MMH types.

The Suppliers see a potential monetary loss (-, risk) due to transactional costs in attempting to build $\mathrm{MMH}$ types in urban core neighborhoods. This is due to restrictions in land use and zoning regulations. To build the MMH types, these restrictions will require changes in the regulations that will entail long and inefficient regulatory processes for approvals (-, risk) (Parolek, 2015 and Interviews \#11, 17). These processes provide the opportunity for neighborhood opposition (-, risk). This results in the suppression of the MMH types.

The Power Brokers / Influencers want neighborhood control, maintenance of the status quo, and no disruption of their lives (Interview \#14). Their fear is that increased density and poor design will lower their property values and disrupt the neighborhood (-, risk). Figure 4 indicated this fear is based on perceptions (-, risks) (Interviews \#6, 21). Consequently, the power brokers influence the regulators to deny the approval for the MMH types and oppose densities in the neighborhood (risk flow). This results in the suppression of the MMH types.

The city regulators have outdated land use and zoning regulations which restrict MMH types (risk). Attempts to change the regulations for higher densities in the neighborhood would require neighborhood approval (risk). The Power brokers influence the city regulators and oppose approval of increased densities (risk flow). This also results in the suppression of the MMH types.

The Capital Investors do not finance properties that are four units or less (risk) (Interviews \#26, 32). They 
need to see positive cash flow and fully leased property before they will finance it (Capital Flow) (Interview \#26, 32). This makes it difficult for for the Supplier. Therefore, there are no MMH types.

Risk reduction capital flow encourages the supply of the MMH types, "Time and Time to Market." Any action, policy, or event which eases or accelerates the process or enhances the rate of the product to market is a $(+, \$)$ Capital Flow to the Supplier and ultimately to the supply of the MMH types. Based on the findings in Figure 7, risk reduction (reversal) can encourage the supply of the MMH types. Figure 7 , illustrates the risk mitigation/reversal and capital flow/infusion, Table 1. The suppliers want no neighborhood opposition, an easy and simple permitting process (reduces time and transaction costs. $(+$, risk reduction low) a land use and regulation code that accommodates higher densities $(+$, risk reduction, incentives such as reduced permitting fees, loosening off-street parking requirements and making vacant city land available (+, risk reduction, Table 1 ). Risk reduction and capital flows are needed for an increase the MMH types.

The power brokers want assurances from the regulators to maintain the status quo and the integrity of the neighborhood (+, risk reduction). They want the keep the existing multifamily units in the neighborhood and suggest expanding and repurposing the units $(+$, Table 1$)$. However, as evidenced in the interviews, they do not have guidelines or suggestions such as samples of architect's drawings on ways to reconfigure, repurpose and expand the existing multifamily units (- to the supplier).

Risk reduction encourages capital flow. Capital flow is denoted by a \$, risk reduction is denoted by a + sign (services, policy changes, reduced fees and, incentives).

The city regulators hold the key (risk mitigation) to capital flow for the suppliers, the power brokers and the capital investors (Table 1). Throughout the interviews, the city regulators suggested strategies to help increase the supply of the MMH types and were willing to facilitate, support and retool its' system (+, risk reduction). As evidenced in the interviews, they are also expected to provide incentives to the Suppliers, educate the Power Brokers, the Capital investors and the suppliers and provide gap financing (\$ capital flow) to mitigate the risk for the Capital Investor (Table 1, Figure 7). Table 1 highlights the observation that the city regulators were awarded the task of providing the capital flow for the suppliers, the power brokers/influencers and the capital investors (Figure 7).

\section{Key Results Relating to Supply Prob- lems and Solutions}

The research conducted in this study clearly reaffirms that there is a supply problem for the "Missing Middle Housing" (MMH) types in urban core neighborhoods. The demand is high in these neighborhoods because of the walkability, proximity to amenities and services as well as the availability of transit services. Based on the findings in this research, these areas are suitable for everyone (starter families, elderly, singles). However, Baby Boomers and Millennials, both have a particularly high affinity for these neighborhoods. The key findings for each category of supply problems are now summarized.

\section{Transportation. Transit and Density for Transpor- tation}

Evidence from the interviews demonstrates respondents recognized the significance of transportation, land use and transit $(34,87 \%, 65$ times $)$, and increased density for transportation (19,49\%, 49 times) for the MMH types. However, respondents recognized both factors were a challenge to solve. Because, density supports transit, there was a dilemma with respondents as to which should come first. Service needs ridership and frequency. Ridership needs density. However, as indicated in Figure 4, there are major issues with density to resolve. Additionally, funding for transit needs to show the need and ridership. Respondents addressed these issues in three ways: 1) Go to the major streets and activity centers to provide increased densities, which will support transit; and 2) Work locally on pedestrian and bike-friendly strategies such as widening sidewalks, narrowing streets, creating bike lanes to provide a sense of security in the streets for walkability and bike-ability; and 3) Work on transit-oriented development techniques such as off-street parking requirements and incentives for developing on the major corridors to encourage development.

\section{Density}

Based on the interviews, density is considered the primary driver in increasing the supply of $\mathrm{MMH}$ types in the urban core (Interviews \#1, 6, 7, 15). However, as the interviews indicate, it is met with opposition by the residents and regulatory limitations (Parolek, 2015). Although density is met with opposition, the research revealed there was a high 
motivation by the respondents to overcome neighborhood opposition and influence and regulatory barriers to increase density (Parolek, 2016). According to evidence from the interviews, there is motivation toward getting suppliers interested in these areas and increasing supply (Interviews \#2, 3, 6, 7, 36).

\section{Affordability}

Affordability was a major concern for the respondents $(22,56 \%, 57$ times). While respondents continued to employ strategies such as land use and zoning changes incrementally to encourage $\mathrm{MMH}$ types, they continued to express concern on affordability due to high land and construction costs, high demand (Market Forces) and described it as a challenge (Interviews \# 1, 23, 24). High demand was a challenge "because people like the area, they want to be here" (Interview \#18). Respondents suggested increased density, relaxed regulations, design techniques and incentives such as parking fee waivers, and available city land for constructing MMH types as ways of reducing costs (Parolek, 2015 and Interviews \# 1,11).

\section{Risk and Capital}

Both developers and lenders perceived significant barriers to $\mathrm{MMH}$ (Interviews \#1, 11, 26, 32). Specifically, the most widely identified barriers to increase MMH supply were neighborhood opposition, regulations, high costs of land, construction and financing, and insufficient developer/banker interest (Parolek, 2015; Shaver, 2017,).

\section{Conclusions}

There is a high demand for diverse mid-rise housing types in walkable urban core areas (Parolek, 2015). These are areas where there is access to parks, entertainment, shopping, services, and mass transit. It suits the lifestyle of all ages but is particularly appealing to millennials and boomers, the two largest demographic groups in the U.S. Supply cannot keep up with the demand. The question is, how can we increase the supply in these areas? Preliminary research with practitioners indicated that the $\mathrm{MMH}$ types are ideal for urban core neighborhoods because they once existed there (Parolek, 2015). However, it is difficult to reintroduce them to the areas because of barriers.

The research findings suggested that the $\mathrm{MMH}$ shortage problem can only be addressed through understanding the flows of risk, risk reduction and capital among four key stakeholder groups: suppliers, power brokers/influencers, city regulators and capital investors.

\section{Suppliers}

The Suppliers are influenced by risk and capital (positively and negatively). They are impacted by three influencers, the power brokers, the city regulators, and the capital investors. The power brokers and the city regulators can negatively impact the supplier. This is further exacerbated by the non- involvement of the capital investors. A common theme in the interviews was the city regulators' willingness to mitigate/remove their risks, facilitate the process with the power brokers and work with the suppliers. However, even with the regulators facilitating the methods, there is still a lack of involvement by the capital investors, which ultimately negatively impacts the supply of MMH types. There is a need for city regulators and suppliers to "work with the capital investors." This research demonstrates Increasing Risk Flow attenuates capital flow and consequently, suppresses the supply of MMH types, "Time and Time to Market" (Interview \#6). It also demonstrates risk reduction encourages capital flow. Risk reduction can be services, policy, time, goodwill in the form of vacant land, reduced fees, incentives, capital is in the form of money and consequently improves the supply of MMH types. Thus, monitoring and managing the process can lead to increased $\mathrm{MMH}$ types.

There are suppliers who persevere despite the land use and zoning restrictions and permitting regulations. They are local; they take the time to learn the regulations, understand the buyer, build relationships with the city regulators to provide a good product (Interviews \# 9, 12, 15). The suppliers who avoid the neighborhoods think it's "too difficult to do," and consequently, do not get involved in the MMH supply. The suppliers perceive that "the preservationists do not want density." However, the preservationists, say "repurpose and expand" (Interview \#34). They want to retain the existing multifamily units in the neighborhood.

\section{Power Brokers/Influencers}

Power brokers/influencers consist of both existing neighborhood residents and special interest groups. They are prone to resist MMH for reasons that include concerns about density (and attendant traffic), poor design, negative impact on existing property values, loss of the existing neighborhood status quo, and loss of control of the existing neighborhood (Interviews \#1, 2, 3, 11, 14). The interviews suggested, however, that they could be reassured, particularly if $\mathrm{MMH}$ plans included ensuring the historic integrity of existing properties (many of which were originally developed as $\mathrm{MMH}$ ), maintaining the neighbor- 
hood character and expanding facilities available to the neighborhood (Interview \#33). Some respondents also suggested that the solution might be to move outside of existing neighborhoods, where resident stakeholder resistance would be minimized (Interviews \#16, 22, 30).

\section{City Regulators}

The research finds that regulators are implementing multiple strategies within their realm of control to increase the supply of MMH (Interviews \#4, 5, 7, 28, 31). As one regulator indicated, "These are fixable." (Interview \#7) They are updating/modernizing the land use and zoning regulations to accommodate additional accessory units with single-family units within the urban core, reduce impact fees for units that are 750 sq. $\mathrm{ft}$. or less as an incentive for the property owner to invest in an accessory unit and have an income stream at the same time (Interview \#5).

The city regulators budgeted and implemented "Complete Streets" strategies by retrofitting streets from one-way high velocities to two-way traffic flow. They are lowering speed limits and expanding sidewalks and other ancillary items to promote safety and making the areas more pedestrian (walkable) and bike-friendly (Interview \#5). However, the density increases, as cited by the respondents for increasing the MMH supply in the urban core, are not occurring at this time. The regulators will not increase the density without the power brokers' approval. As one respondent stated, "We listen to the neighborhoods, we are a city of neighborhoods" (Interview \#21). Instead, the plan is to go out into the neighborhoods to educate and clarify misconceptions regarding fears of property devaluation. The potential residents receive feedback on what is their vision for the area regarding density. For example, "...positively help the public visualize density..." (Interviews \#6, 7, 36). The interviews suggested the need to "work with Suppliers and capital investors to understand their needs", limitations, clarify misconceptions and collaborate to increase the supply of MMH types (Interviews \#6, $7,36)$.

\section{Capital Investors}

City regulators reported it's difficult for the supplier to get funding from the capital investors. However, the capital investors will not lend until the property is leased and shows a positive cash flow. Additionally, units of four and under are not their market, due to the risk involved. Capital investors expressed an interest if gap financing is provided. One capital investor indicated she was working on a program to help developers with funding (Interview \#37).

\section{Directions for Future Research}

Because of the complexity of the issues, many areas need further research. Each of the factors that af- fect the supply of the MMH types needs further research. Evidence is provided in this research for the investigation to reduce or mitigate the risk flow and increase capital flow.

\section{Capital Investors}

Capital investors suggested gap financing could help mitigate their risk (Interview \#26). An investigation of the capital investor's interests and willingness to be involved in a program to finance suppliers with gap financing, is necessary. Opportunities or options for funding sources for the gap financing will be necessary.

\section{Power Brokers}

Evidence in the interviews suggested educating and informing power brokers to help eliminate negative perceptions of increased density (Interviews \#6, 7, $11,36)$.

\section{Suppliers/Developers}

Evidence in the interviews suggested, "time, and time to market" (Interviews \#6, 7, 10, 15) were important factors for the suppliers. Thus, factors which minimize the risks to "time and time to market" may attract the supplier. Further investigation of the reduction of time, and time to tarket could be useful in attracting the supplier to help increase the supply of MMH types. Future research may also include theory on the supplier's role in helping to increase the supply of MMH types. One respondent suggested developing and cultivating an alliance with the suppliers. Further investigation on developing such an alliance will be useful to the local area.

\section{Transportation and Affordability}

While transportation and transit do not have a direct effect on the supply, it is perceived to be a result of the supply.

\section{References}

Area Development. (2009). Quality of life factors into business location decision: Dec/Jan 2009. Retrieved from http://www.areadevelopment.com/ siteSelection/dec08/quality-of-life-business-location017.shtml.

Burks, B. (2017). Finding the missing middle - an opportunity to complete the spectrum of housing options in Tampa Bay: Forward Pinellas, December 13, 2017. Retrieved from http://forwardpinellas.org/blog/finding-missing-middle-opportunity-complete-spectrum-housing-options-Tampa-bay/.

Cervero, R. (1996). Traditional neighborhoods and commuting in the San Francisco Bay Area. Transportation, 23(4), 373-394. doi:https://doi. org/10.1007/BF00223062

Congress of New Urbanism. (2018). What is new urbanism? : Congress of New Urbanism, Wash- 
ington, DC. Retrieved from https://www.cnu.org/ resources/what-new-urbanism.

Corbin, J., \& Strauss, A. L. (2014). Basics of qualitative research (4th ed.): Sage.

Creswell, J. W. (2013). Qualitative inquiry \& research design: Choosing among five approaches (3rd ed.). Thousand Oaks, CA: Sage Publications.

Doherty, C. (2017). The great American single-family home problem: The New York Times, December 1, 2017. Retrieved from https://www.nytimes. com/2017/12/01/business/economy/single-family-home.html.

Federal Financial Institutions Examination Council. (2019). Community Reinvestment Act - Background and purpose. Retrieved from https:// www.ffiec.gov/cra/history.htm

Florida Housing Finance Corporation. (2018). Florida extremely low income approach-proposed May 19,2018. Retrieved from https://www.floridahousing.org/docs/default-source/programs/developers-multifamily-programs/2018-2019-rfa-comments/proposed-eli-maximum-ami-5-19-2018. pdf?sfvrsn=1768327b_2.

Glaeser, E., \& Gyourko, J. (2018). The economic implications of housing supply. Journal of Economic Perspectives, 32(1), 3-30. doi:10.1257/jep.32.1.3

Hertz, D. B. (1979). Risk analysis in capital-investment. Harvard Business Review, 57(5), 169181. Retrieved from https://hbr.org/1979/1909/ risk-analysis-in-capital-investment.

HUD User. (2019). Low-income housing tax credits. Office of Policy Development and Research (PD\&R). Retrieved from https://www.huduser. gov/portal/datasets/lihtc.html.

Koebel, C. T., Lang, R. E., \& Danielsen, K. A. (2004). Community acceptance of affordable housing: National Association of Realtors; Virginia Tech Center for Housing Research and Metropolitan Institute. https://digitalscholarship.unlv.edu/sea_ fac_articles/350.

Kolson, A. H. (2016). Will U.S. cities design their way out of the affordable housing crisis? : Next City, January 18, 2016. Retrieved from https://nextcity. org/features/view/cities-affordable-housing-design-solution-missing-middle.

LaRossa, R. (2005). Grounded theory methods and qualitative family research. Journal of marriage and Family, 67(4), 837-857. doi:https://doi. org/10.1111/j.1741-3737.2005.00179.x

Leyden, K. M. (2003). Social capital and the built environment: The importance of walkable neighborhoods. American journal of public health, 93(9), 1546-1551. doi:10.2105/AJPH.93.9.1546

Lucy, W. H., \& Phillips, D. L. (2006). Tomorrow's cities, tomorrow's suburbs. Chicago, IL: American
Planning Association.

Myers, D., \& Ryu, S. (2008). Aging baby boomers and the generational housing bubble: Foresight and mitigation of an epic transition. Journal of the American Planning Association, 74(1), 17-33. doi:https://doi.org/10.1080/01944360701802006

Ojah Maharaj, S. (2020). Factors affecting the supply of "missing middle" housing types in walkable urban core neighborhoods. Muma Business Review, 4(1), 1-15.

Opticos Design Inc. (2018). Missing middle: Responding to the demand for walkable urban living: Retrieved from http://missingmiddlehousing.com/contact/.

Parolek, D. (2015). 21st century zoning: Responding to the demand for a walkable urban living. Phoenix, AZ: ULI/Reinventing Phoenix. Available from http://siz45zccow2xygm413e57r11-wpengine. netdna-ssl.com/wp-content/uploads / sites/8/2012/03/050515_ULIPHoenix_DParolek_Form-BasedCodesWalkableUrbanism_reduced.pdf.

Parolek, D. (2016). Missing middle housing: Supplying diverse housing options along a spectrum of affordability. Journal of Case Study Research: A Publication of the Center for California Real Estate, 1(1), 32-35.

Rao, P. K. (2013). Development finance: Springer Science \& Business Media.

Shaver, K. (2017). Cities turn to 'missing middle' housing to keep older millennials from leaving The Washington Post, December 9, 2017. Retrieved from https://www.washingtonpost. $\mathrm{com} /$ local/trafficandcommuting/cities-turn-tomissing-middle-housing-to-keep-older-millennials-from-leaving/2017/12/09/3a129bc8d54a-11e 7-95bf-df7 c 19270879 _story. html?utm_term $=.28 \mathrm{ba} 04 \mathrm{~b} 26 \mathrm{~b} 9 \mathrm{c}$.

Vision 2020 Delegates. (2002). St. Pete Vision 2020: The past, present \& future of St. Petersburg: Retrieved from https://www.stpete.org/stpete/vision2020book.pdf.

Woo, A. (2016). The affordability crisis: What happens when Millennials can't afford to buy homes? : Apartment List, April 13, 2016. Retrieved from https://www.apartmentlist.com/rentonomics/ millennials-and-homeownership-2016/.

\section{Review}

This article was accepted under the constructive peer review option. For futher details, see the descriptions at:

http://mumabusinessreview.org/peer-review-options/ 


\section{Author}

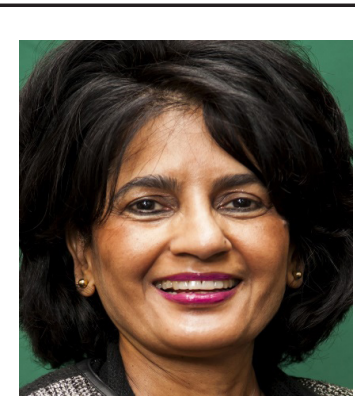

Shrimatee Ojah Maharaj has more than 25 years' experience with the city of St Petersburg in Urban Planning, neighborhood /business corridor planning and redevelopment, economic development and small business retention and expansion. Originally from Trinidad and Tobago, she recently graduated from the Muma College of Business, University of South Florida with the Doctor in Business Administration (DBA), a graduate of the University of Florida, Master's in Urban and Regional Planning (MAURP) and the Bachelor of Science, General, University of the West Indies, Trinidad. She is also a founding member on the advisory board for the Gibbs High School, BETA Program (Business Economics and Technology Academy) and on the Board of directors' member for the Pinellas Opportunity Council, a social action/anti-poverty organization.. 


\section{Appendix 1 - A breakdown of Figure 3 by Supply Problems (Risk) and Supply Solutions (Risk Reduction)}

\begin{tabular}{|c|c|c|c|c|c|c|c|}
\hline Supply Problems & $\begin{array}{c}\text { Files } \\
\mathrm{N}=39\end{array}$ & $\%$ & $\begin{array}{c}\text { \# of } \\
\text { Open } \\
\text { Codes }\end{array}$ & Supply Solutions & $\begin{array}{c}\text { Files } \\
\mathrm{N}=39\end{array}$ & $\%$ & $\begin{array}{c}\text { \# of } \\
\text { Open } \\
\text { Codes }\end{array}$ \\
\hline \multicolumn{4}{|l|}{ NEIGHBORHOODS } & \multicolumn{4}{|l|}{ NEIGHBORHOODS } \\
\hline $\begin{array}{l}\text { Neighborhood Power \& Influ- } \\
\text { ence with politicians }\end{array}$ & 7 & $18 \%$ & 12 & Overcome Barriers & 34 & $87 \%$ & 38 \\
\hline $\begin{array}{l}\text { Neighborhood \& Save The } \\
\text { Burg Opposition }\end{array}$ & 5 & $13 \%$ & 5 & Increase Density for MMH & 26 & $67 \%$ & 57 \\
\hline Neighborhood Fear of Change & 13 & $33 \%$ & 16 & Educate the Neighborhoods & 6 & $15 \%$ & 6 \\
\hline $\begin{array}{l}\text { Neighborhood Feelings, Safe- } \\
\text { ty, Stability }\end{array}$ & 14 & $36 \%$ & 20 & & & & \\
\hline Neighborhood Perceptions & 13 & $33 \%$ & 16 & & & & \\
\hline \multicolumn{4}{|l|}{ LENDERS * \# of Lenders 3} & \multicolumn{4}{|l|}{ LENDERS } \\
\hline Supply Problem & 10 & $26 \%$ & 20 & Supply Solutions & 7 & $18 \%$ & 10 \\
\hline Barriers & 9 & $23 \%$ & 14 & Dodd Frank Not a Problem & 2 & $5 \%$ & 2 \\
\hline Lenders Not Financing & 3 & $8 \%$ & 3 & Employer Assistance & 3 & $8 \%$ & 5 \\
\hline Banks are Risk Averse & 2 & $5 \%$ & 4 & $\begin{array}{l}\text { Practitioners Need to Work } \\
\text { with Lenders \& Developers }\end{array}$ & 9 & $24 \%$ & 20 \\
\hline \multicolumn{4}{|l|}{ DEVELOPERS, \# of Developers 10} & \multicolumn{4}{|l|}{ DEVELOPERS } \\
\hline Challenges & 14 & $36 \%$ & 21 & Motivated Developers & 26 & $67 \%$ & 65 \\
\hline MMH Difficult to do & 5 & $13 \%$ & 7 & $\begin{array}{l}\text { Practitioners Need to Work } \\
\text { with Developers }\end{array}$ & 12 & $31 \%$ & 32 \\
\hline Regulations - Barriers & 17 & $44 \%$ & 54 & Regulations and Incentives & 8 & $21 \%$ & 14 \\
\hline Regulations & 14 & $36 \%$ & 19 & Defray Construction Costs & 13 & $33 \%$ & 29 \\
\hline Process is too Long & 6 & $15 \%$ & 7 & $\begin{array}{l}\text { Educate the Developers \& } \\
\text { Share City Information }\end{array}$ & 5 & $13 \%$ & 8 \\
\hline Construction Costs & 7 & $18 \%$ & 10 & Provide Incentives & 12 & $31 \%$ & 19 \\
\hline Barriers and Market Forces & 10 & $26 \%$ & 18 & Provide Vacant City Land & 4 & $10 \%$ & 15 \\
\hline \multicolumn{4}{|c|}{ CITY REGULATORS, PRACTITIONERS } & \multicolumn{4}{|c|}{ CITY REGULATORS, PRACTITIONERS } \\
\hline Complex & 11 & $28 \%$ & 18 & $\begin{array}{l}\text { Role of Practitioners in } \\
\mathrm{MMH}\end{array}$ & 10 & $27 \%$ & 16 \\
\hline Government & 3 & $8 \%$ & 21 & Overcome Barriers for $\mathrm{MMH}$ & 34 & $89 \%$ & 38 \\
\hline \multirow[t]{3}{*}{ Challenges } & 5 & $13 \%$ & 5 & Strategies for $\mathrm{MMH}$ & 11 & $28 \%$ & 38 \\
\hline & & & & $\begin{array}{l}\text { Use Mobile Home Parks for } \\
\text { MMH }\end{array}$ & 4 & $10 \%$ & 8 \\
\hline & & & & $\begin{array}{l}\text { More Single- Family Neigh- } \\
\text { borhoods for MMH }\end{array}$ & 3 & $8 \%$ & 8 \\
\hline
\end{tabular}

$\mathrm{N}=39,{ }^{\star}$ \# of Lenders 3; \# of Practitioners 20; \# of Developers, 10; (includes realtor/developer) \# of Special Interest, 6; (Neighborhood and Community Interest Groups). 